\title{
Promotion of Early Gut Colonization by Probiotic Intervention on Microbiota Diversity in Pregnant Sows
}

Katarina Veljović ${ }^{1}$, Miroslav Dinić ${ }^{1,2}$, Jovanka Lukić ${ }^{1}$, Sanja Mihajlović ${ }^{1}$, Maja Tolinački ${ }^{1}$, Milica Živković ${ }^{1}$, Jelena Begović ${ }^{1}$, Igor Mrvaljević ${ }^{2}$, Nataša Golić ${ }^{1 *}$ and Amarela Terzić-Vidojević ${ }^{1}$

'Laboratory for Molecular Microbiology, Institute of Molecular Genetics and Genetic Engineering, University of Belgrade, Belgrade, Serbia, ${ }^{2}$ Centre for Development and Production, Veterinary Station "Koker", Adaševci, Serbia

OPEN ACCESS

Edited by:

Giovanna Suzzi,

Università di Teramo, Italy

Reviewed by:

Rosanna Tofalo,

Università di Teramo, Italy

Isabel Hennig-Pauka,

Veterinärmedizinische Universität

Wien, Austria

*Correspondence: Nataša Golić

natasag@imgge.bg.ac.rs

Specialty section:

This article was submitted to

Food Microbiology,

a section of the journal

Frontiers in Microbiology

Received: 27 April 2017 Accepted: 04 October 2017 Published: 20 October 2017

Citation:

Veljović K, Dinić M, Lukić J, Mihajlović S, Tolinački M, Živković M, Begović J, Mrvaljević I, Golić N and Terzić-Vidojević A (2017) Promotion of Early Gut Colonization by Probiotic Intervention on Microbiota Diversity in Pregnant Sows.

Front. Microbiol. 8:2028. doi: 10.3389/fmicb.2017.02028
The aim of this work was to design a novel mixed probiotic culture for piglets and to evaluate its beneficial effect on the piglets' gut health. The possible mechanisms of probiotic activity, such as adhesion, competitive pathogen exclusion and influence on gut microbiota diversity were determined. Mixed probiotic starter culture is composed of three thermophilic lactic acid bacteria (LAB) strains: Lactobacillus helveticus BGRA43, Lactobacillus fermentum BGHI14 and Streptococcus thermophilus BGVLJ1-44. The strains BGVLJ1-44 and BGRA43 showed good technological properties (fast milk curdling, strong proteolytic activity). In addition, the strain BGVLJ1-44 produces exopolysaccharide (EPS), BGHI14 is heterofermentative LAB strain with significant immunomodulatory effect, while the strain BGRA43 showed strong antimicrobial activity against different pathogens and exhibited significantly higher level of adhesion to Caco-2 cells comparing to other two strains. Both lactobacilli strains BGRA43 and BGHI14 $(p<0.05)$, as well as probiotic combination $(p<0.01)$ significantly reduced the adhesion of Escherichia coli ATCC25922 to Caco-2 cells, while the strains BGVLJ1-44 $(p<0.01)$ and BGRA43 $(p<0.05)$ significantly reduced adhesion of Salmonella 654/7E (veterinary isolate). The results of farm trial revealed that treatment of sows with new fermented dairy probiotic influenced the piglets' gut colonization with beneficial bacteria and reduced the number of enterobacteriaceae in litters from some treated sows (no significant due to high variability among animals). Finally, this is the first study reporting that the treatment of sows with probiotic combination resulted in the improved microbiota diversity in neonatal piglets.

Keywords: probiotic, pathogen exclusion, neonatal piglets, microbiota diversity, DGGE

\section{INTRODUCTION}

The establishment of gut microbiota immediately after birth is a prerequisite for the healthy animals. In the first days after birth animals are prone to bacterial infections from the environment and it is extremely important for development of their immune system. Probiotics, defined as "live microorganisms, which when administered in adequate amounts confer a health benefit on the 
host" (FAO-WHO, 2006), could be used as mono- or mixed cultures. The probiotic bacteria have a number of beneficial effects, including immunomodulation, pathogen exclusion and positive influence on maintenance of gut microbiota composition. Probiotics can decrease the incidence and severity of diarrhea caused by ETEC (Kyriakis et al., 1999). Lately, the numbers of studies are intensively engaged in the development of probiotic products for animals, based on the use of lactic acid bacteria (LAB), Bacillus sp. or yeasts together with their associated products such as organic acids and exopolysaccharides. The in vitro adhesion of ETEC to porcine erythrocytes was reduced by exopolysaccharides (EPS) produced by Lactobacillus reuteri (Wang et al., 2010). Similarly, the protective role of the EPS-producing Lactobacillus paraplantarum BGCG11 on HT29-MTX challenged with Escherichia coli was shown previously, as well as the ability of EPS-SJ producing strain Lactobacillus paracasei subsp. paracasei BGSJ2-8 to reduce the E. coli ATCC25922's association to Caco- 2 cells (Živković et al., 2015, 2016). In addition, it has been shown that feed fermentation can deliver such a combination of probiotic lactobacilli that prevent pathogen adhesion (van Winsen et al., 2001; Yang et al., 2015). Due to the synergistic effects, the mixed-probiotic cultures can be more active against different pathogens, as well as in term of improving the colonic health and nutrition (Umesaki and Setoyama, 2000; Timmerman et al., 2004; Collado et al., 2007).

The increased interest in use of probiotics in livestock has arisen since 2006 when the use of antibiotics as growth promoting factors in livestock has been banned by European Union (Castanon, 2007). The most desirable probiotics features in livestock production are generally related to growth promotion in farm animals, improvement of nutrient digestibility, protection from intestinal infections, immunomodulation, and replacement of beneficial microorganisms that are absent from intestinal tract due to disbiosis (Cho et al., 2011). It has been increasingly acknowledged that ingestion of beneficial microorganisms immediately after birth has a remarkable impact on the piglets' postnatal development, referred to as 'microbial imprinting' (Zoetendal et al., 2001; Mazmanian et al., 2005; Konstantinov et al., 2006). On the other hand, in that period piglets might be infected by pathogenic bacteria causing intestinal infections accompanied by diarrhea, weight loss and even mortality. In order to assess the efficacy of probiotics and to ensure the permanent or transient colonization of piglets' intestinal mucosa, the most appropriate time of probiotics' applications should be considered. Ideally, bacterial 'imprinting' should happen in very early life, meaning that the piglets should be exposed to a beneficial microbiota at the time of birth in order to be protected against environmentally acquired pathogens (Kenny et al., 2011). On the other hand, for optimal use in a farm setting, probiotics need to be cost-effective. Thus, the most suitable and cost effective way of probiotic application on pig farms might be the treatment of sows, providing the neonatal piglets with desirable microbes immediately after birth, together with the passive immunity from the treated mothers. Relatively few studies reported the application of LAB in sows. It was observed that administration of L. johnsonii XS4 toward the end of pregnancy and during lactation had positive effects on the sows and piglets, including a significant increase of IgG levels in serum (Wang and Donovan, 2015; Yang et al., 2015).

In this study probiotic and technological properties of two human intestinal isolates Lactobacillus helveticus BGRA43 and Lactobacillus fermentum BGHI14 and one dairy natural isolate from artisanal yogurt Streptococcus thermophilus BGVLJ1-44 were evaluated. The strain BGRA43 exhibits wide range of antimicrobial activity against number of pathogens (Strahinic et al., 2013), BGHI14 was shown to have immunomodulatory potential in a way to burst immune response (Lukic et al., 2013), while BGVLJ1-44 produces ropy exopolysaccharide (EPS) and has good technological characteristics as dairy starter culture. Here we present the potential of the strains for adhesion to epithelial intestinal cells and pathogen exclusion (in vitro), as well as the ability of the mixed probiotic culture to influence the gut microbiota of weaning piglets and to prevent the occurring of intestinal infections (in vivo in farm trial). According to our knowledge, this is the first study reporting that the probiotic intervention on sows resulted in the improved microbiota diversity in neonatal piglets.

\section{MATERIALS AND METHODS}

\section{The Strains and Growth Conditions}

Three thermophilic lactic acid bacteria species from laboratory collection of Laboratory of Molecular Microbiology, Institute of Molecular Genetics and Genetic Engineering, University of Belgrade, Serbia were used in this study: Lactobacillus helveticus BGRA43 (Acc. No. LN909514) isolated from human intestinal tract (Strahinic et al., 2013), Lactobacillus fermentum BGHI14 (Acc. No. LN909513) isolated from newborn feces of a breastfed infant (Lukic et al., 2013) and Streptococcus thermophilus BGVLJ1-44 (Acc. No. LN909512) isolated from an artisanal yogurt produced from uncooked cow's milk.

For the cultivation of $S$. thermophilus BGVLJ1-44 liquid and solid M17 medium (Merck GmbH, Darmstadt, Germany), supplemented with glucose $(0.5 \% \mathrm{w} / \mathrm{v})$ (GM17) was used, while for the cultivation of strains L. fermentum BGHI14 and L. helveticus BGRA43 liquid and solid MRS medium (Merck, $\mathrm{GmbH}$ ) was used. The strains were grown at $37^{\circ} \mathrm{C}$, in anaerobic condition using Anaerocult A (Merck). Solid medium plates were prepared by adding agar ( $1.7 \%$ w/v, Torlak, Belgrade) into each medium broth. Esherichia coli ATCC25922 and Salmonella typhimurium Enteriditis 654/7E (veterinary isolate, the Collection of Scientific Institute of Veterinary Medicine, Novi Sad, Serbia) were cultivated in Luria-Bertani broth (LB) at $37^{\circ} \mathrm{C}$.

\section{Physiological, Biochemical and Technological Characterization of Strains}

The strains L. helveticus BGRA43, L. fermentum BGHI14 and S. thermophilus BGVLJ1-44 were subjected to a set of tests as follows: growth at different temperatures $\left(15^{\circ} \mathrm{C}, 30^{\circ} \mathrm{C}\right.$ and $\left.45^{\circ} \mathrm{C}\right)$; growth in broth with $2 \% \mathrm{NaCl}(\mathrm{w} / \mathrm{v})$; L-arginine 
and esculine hydrolysis, the use of citrate as energy source (Kempler and Mckay, 1981); $\mathrm{CO}_{2}$ production from glucose in reconstituted MRS broth tubes containing inverted Durham bells; the production of acetoin by the Voges-Proskauer test (Zourari et al., 1991); diacetyl production was tested only qualitatively. After overnight incubation of $11 \%$ reconstituted skimmed milk (RSM) at $37^{\circ} \mathrm{C}, 1 \mathrm{ml}$ of coagulated milk was mixed with $0.1 \mathrm{~g}$ of creatinine (Alfa Aesar, GmbH \& Co KG, Karlsuhe, Germany) and $1 \mathrm{ml}$ of $30 \% \mathrm{NaOH}(\mathrm{w} / \mathrm{v})$. Diacetyl production was indicated by the formation of a red halo at the top of the tubes after $2 \mathrm{~h}$ of incubation at room temperature. EPS production was detected visually on MRS or GM17 agar plates, depending on the strain, as long strands when the colonies were extended with an inoculation loop (Nikolic et al., 2012). Speed curdling was determined visually by time measuring from the moment of inoculation of $11 \%$ sterile RSM with each single starter culture to the moment of curd forming at the incubation temperature of $42^{\circ} \mathrm{C}$. Test in litmus milk was prepared in RSM with litmus indicator. After overnight incubation of inoculated RSM at $37^{\circ} \mathrm{C}$ the changes of color and structure of litmus milk were detected according to Cappuccino and Sherman (2010) as follows: A-acid production (red ring); C-curdling (milk curdled due to lactose fermentation) and R-reduction of $\mathrm{H}^{+}$ions (white color). Test of surviving of the strains BGRA43, BGHI14 and BGVLJ1-44 in MRS and GM17 broth after heating at $63.5^{\circ} \mathrm{C}$ for 30 min was performed too. Aggregation ability of tested starter cultures was detected visually after shaking of tubes with inoculated MRS or GM17 broth that were previously incubated overnight at $37^{\circ} \mathrm{C}$.

The proteolytic activity of the isolates BGRA43, BGHI14 and BGVLJ1-44 were assayed as previously described (Kojic et al., 1991). The collected fresh cells (10 mg with an approximate density of $10^{10}$ cells $/ \mathrm{ml}$ ) were resuspended in $0.1 \mathrm{M}$ of sodium phosphate buffer with $\mathrm{pH} 6.8$ and mixed in a 1:1 ratio with $5 \mathrm{mg} / \mathrm{ml}$ of $\alpha_{\mathrm{s} 1^{-}}, \beta$ - and $\kappa$ - casein respectively (Sigma, St. Louis, MO, United States) dissolved in the identical buffer. The mixtures were incubated for $3 \mathrm{~h}$ at $37^{\circ} \mathrm{C}$. The degradation of $\alpha_{\mathrm{s} 1^{-}}, \beta$ and $\kappa$ - casein was analyzed on $12.5 \%$ sodium dodecyl sulfatepolyacrylamide gel electrophoresis (SDS-PAGE). The level of $\alpha_{s 1}-, \beta$ - and $\kappa$ - casein degradation was quantified by ImageQuant software (Molecular Dynamics GmbH, Krefeld, Germany).

\section{Survival of the Strains in Simulated Gastrointestinal Tract Transit}

Survival of probiotic strains after the chemically simulated gastrointestinal tract (GIT) transit was essentially performed as described previously (Nikolic et al., 2012), with minor modifications. The strains were grown in appropriate medium for $24 \mathrm{~h}$ and cultures were harvested by centrifugation $(10,000 \times g$ for $10 \mathrm{~min}$ ), washed twice with $0.85 \% \mathrm{NaCl}$ and concentrated 10-times in reconstituted (10\%) sterilized skimmed-milk (Difco, Becton Dickinson, Franklin Lakes, NJ, United States) or in saline buffer $(0.85 \% \mathrm{NaCl})$. Afterward, bacterial suspensions were diluted 10-times with gastric juice (GJ: $125 \mathrm{mM} \mathrm{NaCl}, 7 \mathrm{mM}$ $\mathrm{KCl}, 45 \mathrm{mM} \mathrm{NaHCO} 3,0.3 \%$ Pepsine [Sigma, St. Louis, MO, United States] adjusted to $\mathrm{pH} 2$ with $\mathrm{HCl}$ ), incubated for $90 \mathrm{~min}$ at $37^{\circ} \mathrm{C}$ in aerobic conditions under shaking $(\approx 180 \mathrm{rpm})$. Then, bacterial suspensions were centrifuged $(2050 \times g, 15 \mathrm{~min})$, resuspended in duodenal juice (DJ: 1\% bovine bile [Sigma] adjusted with $10 \mathrm{M} \mathrm{NaOH}$ to $\mathrm{pH} 8.0$ ) and incubated for $10 \mathrm{~min}$ at $37^{\circ} \mathrm{C}$ in anaerobic condition using Anaerocult A (Merck). Finally, harvested cell suspensions were resuspended in intestinal juice (IJ: $0.3 \%$ bovine bile, $0.1 \%$ Pancreas acetone powder porcine Type I [Sigma], $\mathrm{pH} \mathrm{8.0)}$ and incubated for $120 \mathrm{~min}$ at $37^{\circ} \mathrm{C}$ in anaerobic conditions. Two samples were collected during IJ challenge, after 60 and $120 \mathrm{~min}$. Determination of viable counts was carried out in the initial cultures, as well as after each of the challenges. Serial dilutions of the samples were made in $0.85 \%$ $\mathrm{NaCl}$ and $10 \mu \mathrm{l}$ were spotted onto an appropriate medium. Plates were incubated for $24 \mathrm{~h}$ at $37^{\circ} \mathrm{C}$ and results were expressed as $\mathrm{CFU} / \mathrm{ml}$. The percentage of survival was calculated from the viable counts recovered after each chemically simulated GIT step with respect to the initial counts (\% CFU recovered bacteria/CFU initial bacteria). The experiments were performed in triplicate.

\section{Adhesion of the Strains to Caco-2 Intestinal Epithelial Cells}

Adhesion to Caco-2 intestinal epithelial cells (IEC) was performed as previously described (Nikolic et al., 2012). The colonocyte-like cell line Caco-2 was used to determine the adhesion ability of bacterial strains. Caco-2 was purchased from the European Collection of Cell Cultures (ECACC No. 86010202). The culture and maintenance of the cells was carried out following standard procedures (Sánchez et al., 2010) using DMEM medium for Caco-2. Media and reagents were purchased from Sigma (St. Louis, MO, United States). Caco-2 cells (passage 5-6) were seeded in 24-well plates and cultivated until a confluent differentiated state was reached. For adhesion experiments, $13 \pm 1$ day-old cellular monolayers were used. All strains were cultured for $24 \mathrm{~h}$ and after washing twice with PBS solution were resuspended in the corresponding cell-line media without antibiotics at a concentration of about $10^{8} \mathrm{CFU} / \mathrm{ml}$. Cellular monolayers were also carefully washed and bacterial suspensions were added at a ratio of about 10:1 (bacteria : eukaryotic cell). Adhesion experiments were carried out for $1 \mathrm{~h}$ at $37^{\circ} \mathrm{C}, 5 \% \mathrm{CO}_{2}$ and, afterward, wells were gently washed to release unattached bacteria before proceeding with the lysis of cellular monolayers using $0.25 \%$ Trypsin-EDTA solution (Sigma, St. Louis, MO, United States). Dilutions of samples, before and after adhesion, were made in Ringer's solution and bacterial counts were performed on GM17 and MRS plates. The adhesion was calculated as: \% CFU adhered bacteria/CFU added bacteria. Experiments were carried out in two replicated plates and in each plate three wells were used per sample.

\section{Reduction of E. coli ATCC25922 and Salmonella 654/7E Adhesion to Caco-2 Cells in Presence of the Strains}

The reduction of adhesion of E. coli ATCC25922 and Salmonella 654/7E strains in the presence of probiotic strains was tested on Caco-2 cells as described previously (Živković et al., 2016). The capability of E. coli ATCC25922 and Salmonella 654/7E strains to be associated to the Caco-2 cells in the presence 
and absence of probiotic strains, as well as in the presence of probiotic combination were tested. Bacterial cultures were washed twice with PBS and resuspended in DMEM without antibiotics at a concentration of $\sim 1 \times 10^{7} \mathrm{CFU} / \mathrm{ml}$; this number was corroborated by plate counting in the agar medium specific for each bacterium. The bacterial suspensions containing one of the pathogens or a combination of pathogens and probiotic strains (ratio 1:1) were independently added to the Caco-2 monolayers at a ratio of 10:1, (bacteria : eukaryotic cells; in the case of pathogens - probiotic combination, each bacterial type was added at a ratio of 10:1) and incubated at $37^{\circ} \mathrm{C}$, with $5 \% \mathrm{CO}_{2}$ for $1 \mathrm{~h}$. Afterward, the monolayers were gently washed twice with PBS to remove the unattached bacteria, and the eukaryotic cells were released using 0.25\% Trypsin-EDTA solution (Sigma, St. Louis, MO, United States). The samples were diluted in $0.85 \%$ (w/v) $\mathrm{NaCl}$ buffer and plated to LB medium to enumerate the associated E. coli ATCC25922 and Salmonella 654/7E strains. The percentage of E. coli ATCC25922 and Salmonella 654/7E strains association was calculated as follows: $100 \times \mathrm{CFU} / \mathrm{ml}$ bacteria associated/CFU/ml bacteria added (the dilution of bacteria was taken into account). Each combination was tested in triplicate. To determine the capability of probiotic strains to decrease the association of E. coli ATCC25922 and Salmonella 654/7E strains to Caco-2 monolayers, data were referred to that obtained with the E. coli ATCC25922 and Salmonella 654/7E strains alone, respectively (i.e., 100\% association). Each combination of pathogens and probiotic strains, and the pathogens strain alone, respectively, were tested in three replicates.

\section{Design of Probiotic Culture}

Preparation of fermented probiotic culture includes the milk fermentation process by use of starter and probiotic bacteria in defined ratio. Incubation of inoculated milk was carried at $42^{\circ} \mathrm{C}$ for approximately $5 \mathrm{~h}$ until the $\mathrm{pH} 4.8$ was reached. After that, fermented milk was transferred to the refrigerator at $4^{\circ} \mathrm{C}$ where the $\mathrm{pH}$ of fermented milk is further slowly lowered to 4.6 during cooling. The $\mathrm{pH}$ value and total viable count of probiotic bacteria was estimated immediately after the inoculation of milk as well as each hour during first $5 \mathrm{~h}$ of the milk fermentation and after $24 \mathrm{~h}$, 7,14 , and 21 days of storage of fermented dairy probiotic at $4^{\circ} \mathrm{C}$. Experiments are performed in three independent measurements.

\section{Farm Trial Study Design}

The effect of the probiotic combination (including strains: BGVLJ1-44, BGHI14 and BGRA43) on the health status of farm animals was monitored in vivo in farm trial. The experiments were performed in accordance to the European convention for protection of vertebrate animals used for experimental and other scientific purposes (Directive 2010/63/EU) as well as International Guiding Principles for Biomedical Research involving Animals (C.I.O.M.S., c/o WHO, CH 1211 Geneva 27, Switzerland), and approved by Ethical Committee of Faculty of Biology, University of Belgrade, Serbia; No EK-BF-2013/09). The probiotic strains were prepared in reconstituted (10\%) sterilized skimmed-milk (Difco, Becton Dickinson, Franklin Lakes, NJ, United States). Out of 50 pregnant sows 25 were treated with probiotic combination for 10 days before predicted farrowing term (at a time when the natural immunity of pregnant sows usually declines). Pregnant sows have been received the $200 \mathrm{ml}$ of mixed probiotic culture $\left(10^{8} \mathrm{CFU} / \mathrm{ml}\right)$ every day during the first morning feeding. In parallel, 25 control sows, not treated with the probiotic, were followed. Before and after the probiotic treatment, the general health of treated and control sows and the total number of bacteria (LAB and Enterobacteriaceae) in piglets' faces was followed as described previously (Anonymous, 1996; Terzic-Vidojevic et al., 2007).

\section{Denaturing Gradient Gel Electrophoresis (DGGE) Analysis}

Extraction of bacterial DNA from fecal samples was done using the ZR Genomic DNA Tissue Mini Prep kit (Zymo Research, Irvine, CA, United States). PCR reaction with isolated bacterial DNA as a template, denaturing gradient gel electrophoresis (DGGE) analysis and gel manipulation after electrophoresis was performed essentially as described previously (Lukic et al., 2013). The dominant bacterial communities were determined by PCR using primers U968-GC and L1401-r (Invitrogen, Paisley, United Kingdom) complementary to the V6 to V8 region of eubacterial 16S rDNA (Randazzo et al., 2006), while lactobacilli diversity was detected by lactobacilli-specific primers Lab-0159f and Uni-0515-GCr (Invitrogen, Paisley, United Kingdom) (Lukic et al., 2013). The reaction was performed in thermal cycler Gene AmpR PCR System 2700 (Applied Biosystems, Foster City, CA, United States). Bacterial DNA was then set on denaturing gradient gel prepared according to Lukic et al. (2013) and glass plates for DGGE apparatus DGGE-2001 (C.B.S. Scientific, San Diego, CA, United States) were used.

\section{Enterotoxigenic Escherichia coli and Salmonella sp. Detection}

To detect possible presence of the most common intestinal pathogens in piglets', PCR reactions were performed using as a template $100 \mathrm{ng}$ of DNA extracted from fecal samples [as described in Section "Denaturing Gradient Gel Electrophoresis (DGGE) Analysis"]. Primers used in the study were complementary to eltA gene and invA gene, specific for enterotoxigenic Escherichia coli (Youmans et al., 2014) and Salmonella sp. (Li and Chen, 2013), respectively. PCR reactions were prepared using 10 pmols of each primer, $0.2 \mathrm{mM} \mathrm{dNTP}$ and $0.6 \mathrm{U}$ of Taq Polymerase in a volume of $30 \mu \mathrm{l}$ and run under the following conditions: $94^{\circ} \mathrm{C}$ for $5 \mathrm{~min}$ and then 35 cycles of $94^{\circ} \mathrm{C}$ for $30 \mathrm{~s}, 57^{\circ} \mathrm{C}$ for $60 \mathrm{~s}$ and $72^{\circ} \mathrm{C}$ for $30 \mathrm{~s}$ with a final extension at $72^{\circ} \mathrm{C}, 7 \mathrm{~min}$.

\section{Statistical Analysis}

Differences between treatments were examined for significance by Student's $t$-test after analysis of variance. For comparison of proportions of individual bands on DGGE profiles between piglets from different treatment groups, Pearson's chi-squared test $(\chi 2)$ was applied. Wilcoxon Signed Ranks test was used to compare the number of total bands in DGGE profiles in piglets with the number of bands in their mother sows. $P>0.05$ was considered to be statistically insignificant. 

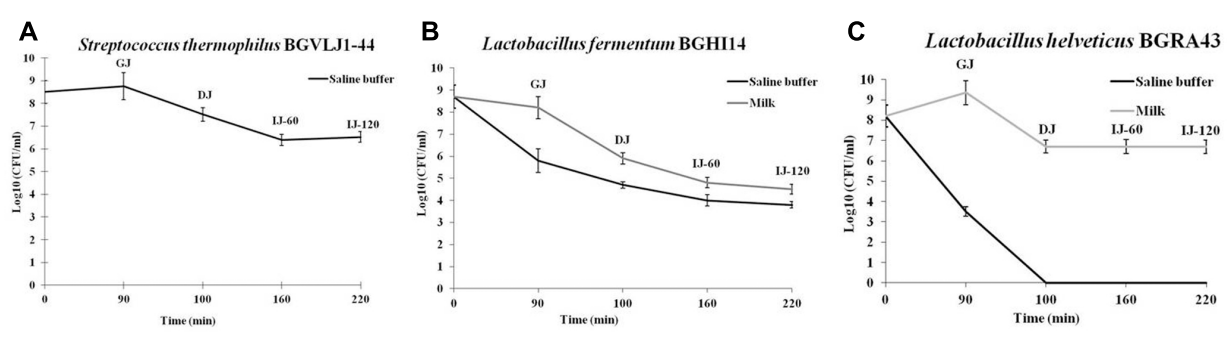

FIGURE 1 | Survival of the strains Streptococcus thermophilus BGVLJ1-44 (A), Lactobacillus fermentum BGHI14 (B) and Lactobacillus helveticus BGRA43 (C) in simulated conditions of the gastrointestinal tract. GJ - time point when samples were taken from chemically simulated gastric juice; DJ - time point when samples were taken from chemically simulated duodenal juice; IJ-60 and IJ-120 - the time points (60 and 120 min, respectively) when samples were taken from chemically simulated intestinal juice. Values represent the means of three experiments. Standard deviations are shown.

\section{RESULTS}

\section{In Vitro GIT Survival of Probiotic Strains}

The survival of probiotic strains S. thermophilus BGVLJ1-44, L. fermentum BGHI14 and L. helveticus BGRA43 after chemically simulated GIT transit was tested. The results revealed that only the strain BGVLJ1-44 successfully survived the passage through simulated GIT conditions in saline buffer, while the strains L. helveticus BGRA43 survived in simulated GIT conditions only when administered in milk (Figure 1). The results showed that the number of viable cells administered in milk after $90 \mathrm{~min}$ was similar to that at the beginning of the experiment in all probiotic strains, indicating that all strains were resistant to acidic conditions. However, 10 min exposure to high bile salts concentration decreased the survival of the strain BGHI14 both in saline ( $\Delta \log \mathrm{CFU} / \mathrm{ml} 1.1)$ and milk ( $\Delta \log \mathrm{CFU} / \mathrm{ml} 2.3$ ), while the strain BGRA43 survived only when administred in milk $(\Delta \log \mathrm{CFU} / \mathrm{ml} 2.65)$. Finally, $120 \mathrm{~min}$ exposure to lower bile salt concentration $(0.3 \%)$ and pancreatic digestion considerably reduced the viability of BGHI14 ( $\Delta \log$ CFU/ml from 0.9 to 1.1 in saline buffer and milk, respectively), as well as the number of viable cells of BGVLJ1-44 ( $\triangle \log C F U / m l ~ 1)$. Interestingly, the number of viable cells of BGRA43 in milk remained the same. The best survival rate showed BGRA43 (3.2\%; $\Delta \log \mathrm{CFU} / \mathrm{ml} 1.5)$ in milk, while the survival rate of BGVLJ1-44 was $1 \% ; \Delta \log$ CFU $/ \mathrm{ml}$ 2 in saline. The lowest survival rate showed BGHI14 (0.01\%; $\Delta \log \mathrm{CFU} / \mathrm{ml} 4.2$ when administered in milk and $0.001 \% ; \Delta \log$ $\mathrm{CFU} / \mathrm{ml} 4.9$ when administered in saline) (Figure 1).

\section{Characterization of Technological Properties of the Strains and Preparation of Fermented Probiotic}

Since the results of in vitro GIT survival showed that the best survival rate of the strains was obtained in milk, the strains S. thermophilus BGVLJ1-44, L. fermentum BGHI14 and L. helveticus BGRA43 were used as starter cultures for preparation of fermented dairy probiotic. The general physiological, biochemical and technological characteristics of the strains are summarized in Table 1. Only L. fermentum BGHI14 strain showed ability to grow at all three tested temperatures $\left(15^{\circ} \mathrm{C}, 30^{\circ} \mathrm{C}\right.$ and $\left.45^{\circ} \mathrm{C}\right)$ and none of them grew in broth with $2 \% \mathrm{NaCl}$. Hydrolysis of arginine and production of $\mathrm{CO}_{2}$ showed L. fermentum BGHI14 strain, while production of acetoin and diacetyl were characteristic for $S$. thermophilus BGVLJ1-44 strain. All three LAB strains survived at $63.5^{\circ} \mathrm{C}$ for 30 min. L. fermentum BGHI14 as heterofermentative strain could not coagulate the milk. On the other hand, the strains S. thermophilus BGVLJ1-44 and L. helveticus BGRA43 showed the ability of fast milk curdling and they completely hydrolyze $\alpha_{s 1-}$, $\beta$ - and $\kappa$-casein after $3 \mathrm{~h}$ of incubation at $37^{\circ} \mathrm{C}$. S. thermophilus BGVLJ1-44 strain was an excellent EPS producer (Table 1).

Appart from milk, the rate of acid development was also followed in whey. The pasteurized milk and way were inoculated each with $3 \%$ probiotic starter culture. Measuring of $\mathrm{pH}$ values during $0,1,2,3,4$, and $5 \mathrm{~h}$ of fermentation at $42^{\circ} \mathrm{C}$, as well as after $24 \mathrm{~h}, 7,14$, and 21 days of storage at $4^{\circ} \mathrm{C}$ was performed. In parallel, total count of viable probiotic LAB was followed (Figure 2). The $\mathrm{pH}$ of non-inoculated milk and whey were 6.81 and 6.65 , respectively.

Probiotic starter culture inoculated in whey decreased $\mathrm{pH}$ value faster than probiotic starter culture inoculated in milk. The $\mathrm{pH}$ value of fermented whey was 4.80 after $4 \mathrm{~h}$ at $42^{\circ} \mathrm{C}$ and $\mathrm{pH}$ of fermented milk was 4.78 after $5 \mathrm{~h}$ of incubation at $42^{\circ} \mathrm{C}$. During the cooling, the $\mathrm{pH}$ values of fermented milk and whey slowly decreased and after 21 days of storage at $4^{\circ} \mathrm{C}$ the $\mathrm{pH}$ values of fermented milk and whey were 4.47 and 4.38 , respectively (Figure 2).

In parallel, total counts of viable probiotic starter cultures during fermentation of milk and whey were followed. The total number of viable LAB increased in milk and whey from $7.5 \mathrm{log}$ $\mathrm{CFU} / \mathrm{ml}$ and $7.4 \log \mathrm{CFU} / \mathrm{ml}$, respectively, at the beginning of incubation period to $8.9 \log \mathrm{CFU} / \mathrm{ml}$ in milk and $8.2 \log \mathrm{CFU} / \mathrm{ml}$ in whey at the end of fermentation at $42^{\circ} \mathrm{C}$. After 21 days of storage of the fermented milk and whey the number of probiotic bacteria in fermented milk and whey was $8.2 \log \mathrm{CFU} / \mathrm{ml}$ and 7.9 $\log \mathrm{CFU} / \mathrm{ml}$, respectively (Figure 2).

\section{Characterization of the Ability of Probiotic Strains to Reduce the E. coli and Salmonella Adhesion to Caco-2 Cells}

In order to determine the ability of the strains $S$. thermophilus BGVLJ1-44, L. fermentum BGHI14 and L. helveticus BGRA43 to 
counteract the adhesion of pathogens, the adhesion properties of the probiotic strains to IEC Caco-2 were determined. The strain BGRA43 showed significantly $(p<0.05)$ higher adhesion of 1.7 to 2.1-fold to Caco-2 cells comparing to BGVLJ1-44 and BGHI14, respectively (Figure 3 ).

Further, the potential of probiotic strains BGVLJ1-44, BGHI14 and BGRA43, as well as the mixed probiotic culture, to compete with E. coli ATCC25922 and Salmonella 654/7E and to reduce their adhesion to Caco-2 cells was studied. The adhesion of E. coli ATCC25922 strain was significantly $(p<0.05)$ lower in the presence of BGRA43 (1.5-fold) and BGHI14 (1.2-fold) lactobacilli strains (Figure 3). The highest reduction (2.6-fold) of E. coli ATCC25922 adhesion to Caco-2 cells was in the presence of the mixed probiotic culture $(p<0.01)$ (Figure 3).

In addition, the adhesion of Salmonella 654/7E to Caco- 2 cells was significantly reduced (16-fold) in the presence of BGVLJ1-44 $(p<0.01)$ and 1.5-fold in the presence of BGRA43 $(p<0.05)$ (Figure 3). Interestingly, there was no reduction of Salmonella $654 / 7 \mathrm{E}$ adhesion in the presence of BGHI14 and probiotic mixture.

\section{In Vivo Evaluation of the Effect of Probiotic Combination on Neonatal Piglets}

Since the results given in Section "In Vitro GIT Survival of Probiotic Strains" showed that the number of probiotic bacteria was higher in fermented milk than in whey, the fermented milk containing probiotic strains L. fermentum BGHI14, L. helveticus BGRA43 and $S$. thermophilus BGVLJ1-44 was used in farm trial.

\section{Farm Trial}

In order to determine possible protective effect of the mixed probiotic culture on neonatal piglets, the farm trial was performed including 50 pregnant sows (25 sows treated with probiotic combination and 25 control sows). The results showed that none of piglets, from litters of sows treated with the mixed probiotic culture, suffered from diarrhea. In contrast, among piglets from control litters diarrhea occurred sporadically. In addition, body weight of the piglets was followed twice a week during the experimental period and the results were in accordance to the results obtained for the control animals. The experimental animals did not show eating disorders.

Importantly, the number of Enterobacteriaceae in fecal samples collected from litters of probiotic treated sows was reduced in treated sows compared to the number of Enterobacteriaceae in the fecal samples of the litters of untreated sows, although the variability among tested animals was high (Figure 4). In order to detect possible presence of ETEC and virulent Salmonella sp. strains in the fecal samples from piglets, the PCR analysis with primers specific for the eltA gene and invA gene, respectively, was performed. However, the bands specific for the eltA gene encoding the heat-labile enterotoxin in ETEC and the invA gene encoding invasive protein in Salmonella sp. were not detected in any of the analyzed samples.

\section{DGGE Analysis}

Gut microbiota diversity, as well as LAB diversity in sows before the probiotic treatment and in litters of treated and untreated sows was evaluated by DGGE analysis. Total DNA isolated from fecal samples, as template, and primers complementary to $16 \mathrm{~S}$ rDNA were used for PCR amplification. In total, 24 randomly

TABLE 1 | Phenotypic, biochemical and technological characteristics of Streptococcus thermophilus BGVLJ1-44, Lactobacillus fermentum BGHI14 and Lactobacillus helveticus BGRA43 strains.

\begin{tabular}{|c|c|c|c|}
\hline Feature tested & $\begin{array}{l}\text { Streptococcus thermophilus } \\
\text { BGVLJ1-44 }\end{array}$ & $\begin{array}{l}\text { Lactobacillus fermentum } \\
\text { BGHI14 }\end{array}$ & $\begin{array}{c}\text { Lactobacillus helveticus } \\
\text { BGRA43 }\end{array}$ \\
\hline Growth at $15^{\circ} \mathrm{C}$ & - & + & - \\
\hline Growth at $30^{\circ} \mathrm{C}$ & + & + & + \\
\hline Growth at $45^{\circ} \mathrm{C}$ & - & + & - \\
\hline Growth in broth with $2 \% \mathrm{NaCl}$ & - & - & - \\
\hline Arginine hydrolysis & - & + & - \\
\hline Esculin hydrolysis & - & \pm & \pm \\
\hline Citrate utilization & - & - & - \\
\hline $\begin{array}{l}\text { Production of } \mathrm{CO}_{2} \text { from } \\
\text { glucose }\end{array}$ & - & + & - \\
\hline Production of acetoin & + & - & - \\
\hline Production of diacetyl & + & - & - \\
\hline Curdling (h) & 6 & No curdling & 6 \\
\hline Litmus milk & $A^{1} C^{2} R^{3}$ & R & ACR \\
\hline Survival at $63.5^{\circ} \mathrm{C}$ for $30 \mathrm{~min}$ & \pm & + & + \\
\hline $\begin{array}{l}\text { Degradation of } \alpha_{\mathrm{s} 1-}, \beta \text { - and } \\
\kappa \text {-casein after } 3 \mathrm{~h} \text { of incubation } \\
\text { at } 37^{\circ} \mathrm{C}\end{array}$ & $\begin{array}{c}\alpha_{\mathrm{s} 1-} \text { casein }(+) \beta \text { - casein }(+) \\
\kappa-\operatorname{casein}(+)\end{array}$ & $\begin{array}{c}\alpha_{\mathrm{s} 1-} \text { casein }(-) \beta \text { - casein }(-) \\
\kappa \text {-casein }(-)\end{array}$ & $\begin{array}{c}\alpha_{\mathrm{S} 1-} \text { casein }(+) \beta \text { - casein }(+) \\
\kappa \text {-casein }(+)\end{array}$ \\
\hline Aggregation & - & - & - \\
\hline $\begin{array}{l}\text { Production of } \\
\text { exopolysaccharides }\end{array}$ & + & - & - \\
\hline
\end{tabular}




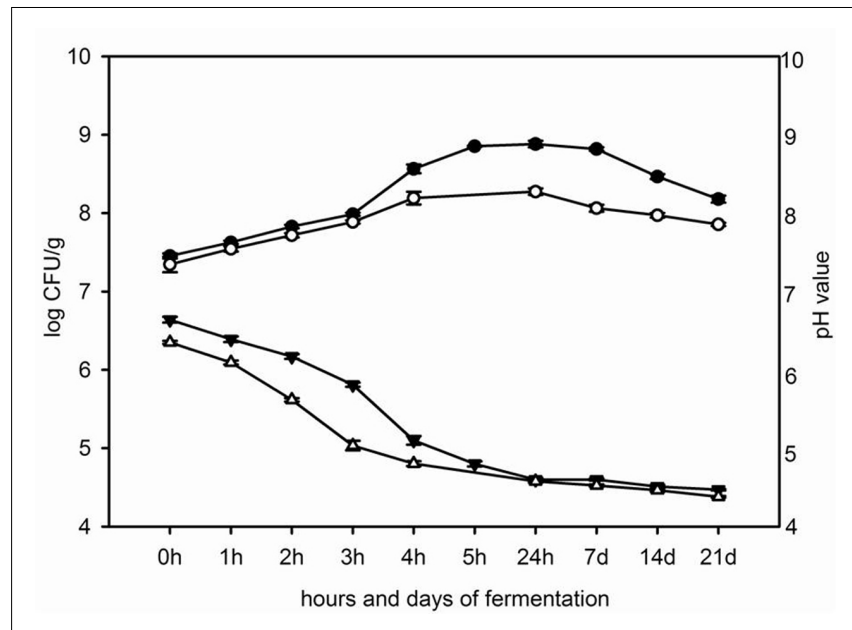

FIGURE 2 | The changes of $\mathrm{pH}$ value in milk $(\mathbf{\Delta})$ and in whey $(\Delta)$ and the total count of viable mixed probiotic starter cultures in milk $(\bullet)$ and in whey $(\bigcirc)$ during fermentation for $5 \mathrm{~h}$ at $42^{\circ} \mathrm{C}$ and 21 days of storage at $4^{\circ} \mathrm{C}$.

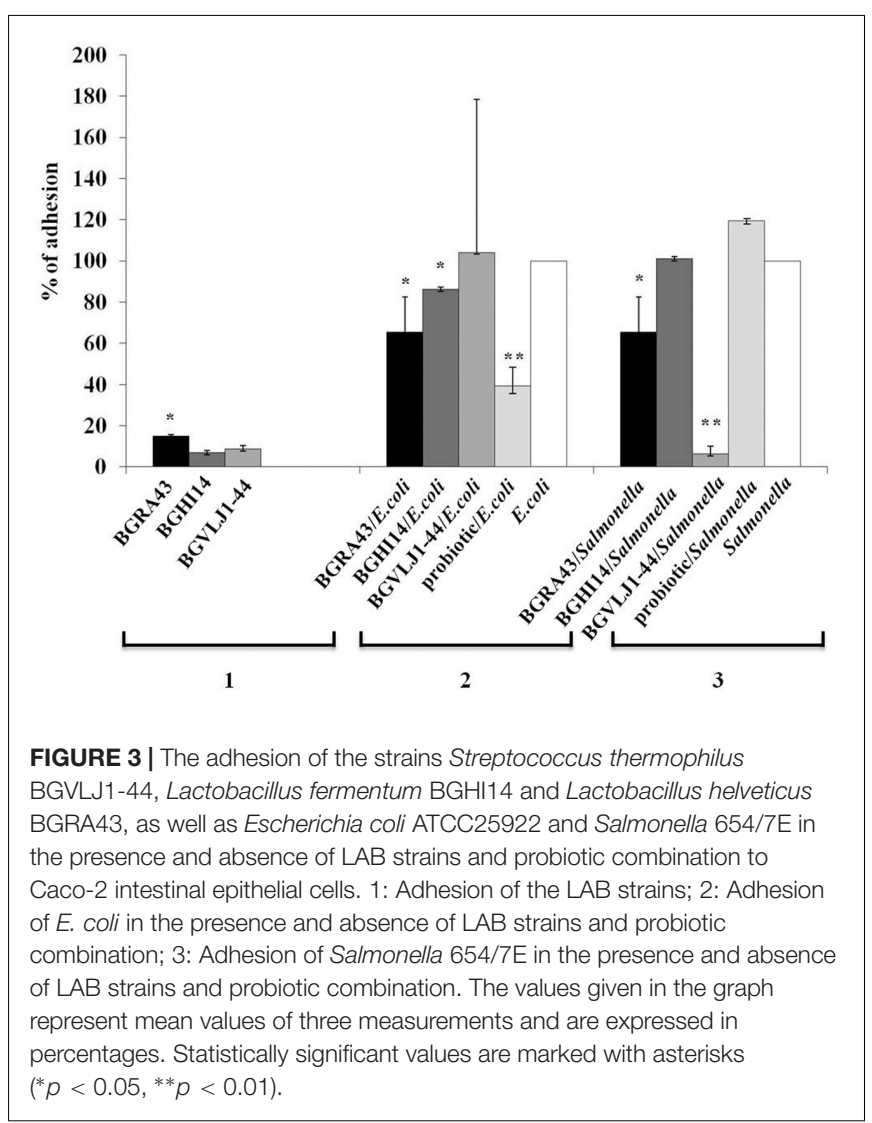

chosen DNA amplicons were used (12 from sows before probiotic treatment, four from litters of control untreated sows and eight from litters of sows treated with probiotic combination) (Figure 5). The presence of specific bands in DGGE profiles of gut microbiota in litters belonging to sows treated with probiotic was evaluated using Pearson's chi-squared test $\left(\chi^{2}\right)$ where only the clearly visible bands were counted. Results of $\chi^{2}$ test revealed

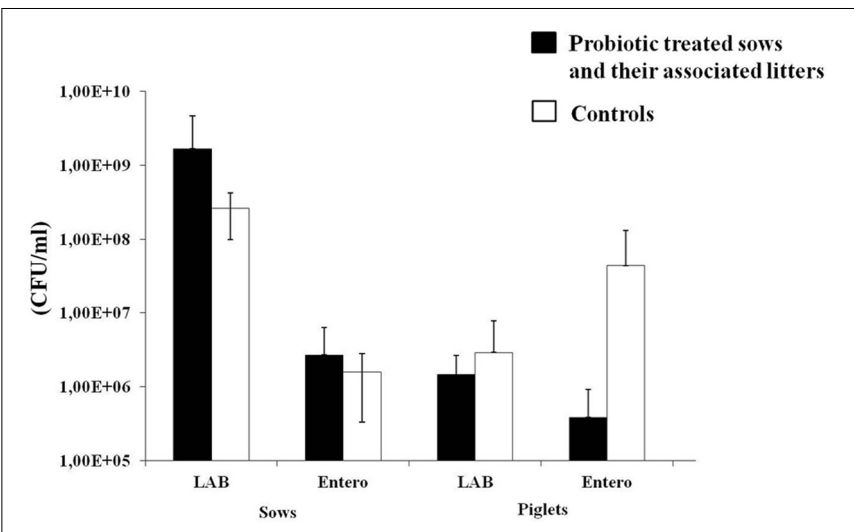

FIGURE 4 | The number (CFU/ml) of lactic acid bacteria (LAB) and Enterobacteriaceae in sows (at the beginning of experiment, before probiotic treatment) treated with probiotic combination and control animals, as well as their associated litters (born after the probiotic treatment). Black bars represent sows treated with probiotic combination and their associated litters (as indicated on $x$-axis). White bars represent control sows and their associated litters (as indicated on $x$-axis). Values represent the means of three experiments. Standard deviations are shown.

that proportions of six bands obtained with Eubacteria-specific primers were significantly higher $(62.5-87.5 \%)(p<0.05)$ and proportions of three bands obtained with the same primers were significantly lower $(50-87.5 \%)(p<0.05)$ in litters of probiotictreated sows (Table 1). Additionally, the analysis detected two bands obtained with lactobacilli-specific primers that were present in significantly lower $(50-62.5 \%)(p<0.05)$ proportions in litters of probiotic-treated sows (Table 1).

Concerning bacterial diversity, results of $t$-test revealed significantly higher average number of bands obtained with Eubacteria-specific primers in litters of treated sows (39) as compared to litters of non-treated sows $(32.75)(p<0.05)$. No differences were obtained with LAB-specific primers. We additionally used matched statistical analysis to compare total bacterial diversity in litters with bacterial diversity in their mother sows, using Wilcoxon Signed Ranks test. This test revealed that probiotic treatment caused an increase of average number of Eubacteria-specific bands in litters $(39)(p<0.05)$ relative to their mothers before treatment (19.75). There were no differences between litters and their mothers in non-treated group. Furthermore, no differences were obtained with LAB-specific bands for none of the treatment groups (Figure 5). Hence, the results indicate that probiotic treatment of pregnant sows positively influenced the gut microbiota diversity of neonatal piglets.

\section{DISCUSSION}

In this study the potential beneficial effect of new fermented dairy probiotic culture based on three natural isolates $L$. helveticus BGRA43, L. fermentum BGHI14 and S. thermophilus BGVLJ1-44 was investigated. The main aim was to establish the gut health and promote gut colonization of neonatal piglets with beneficial 

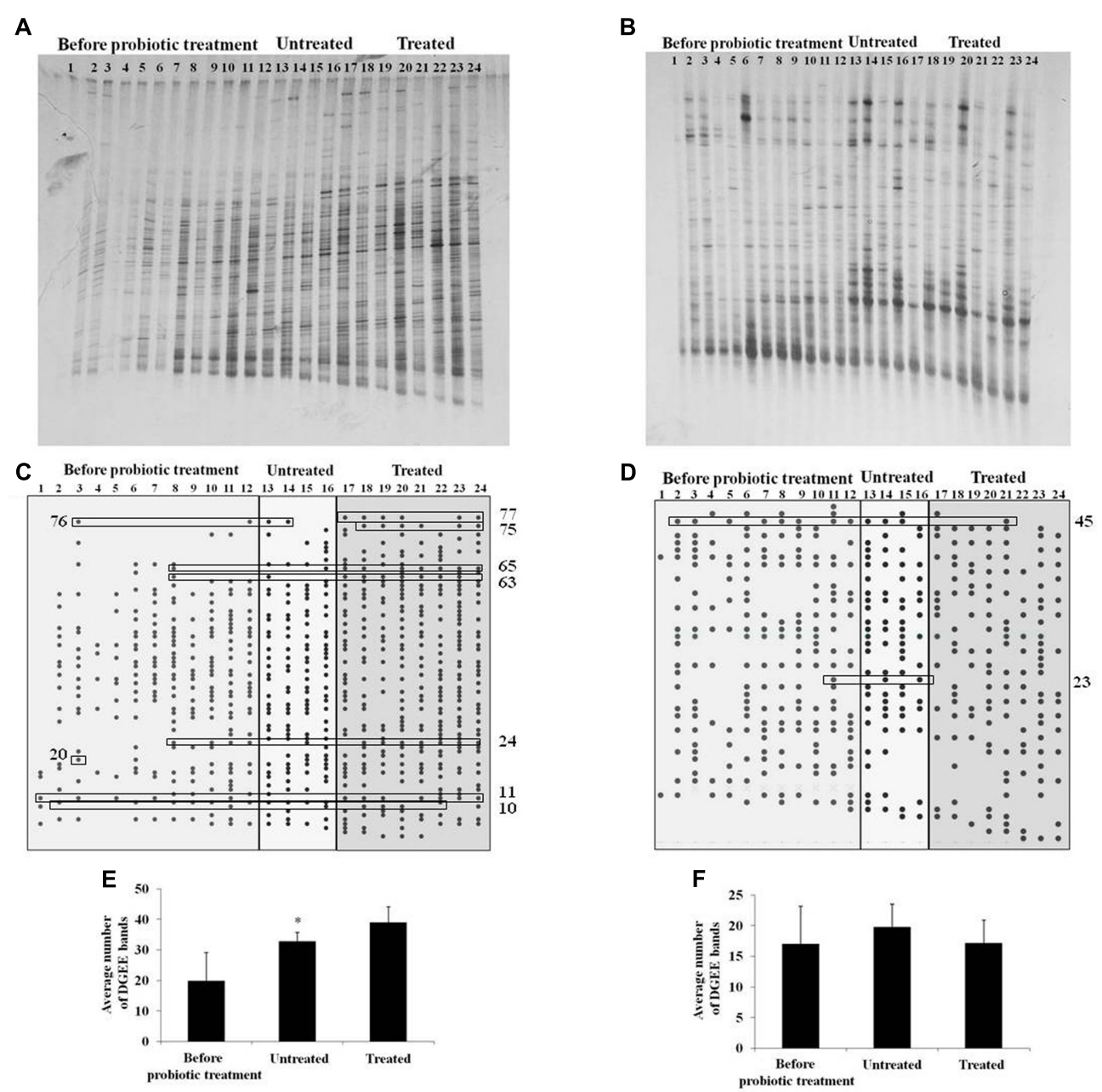

FIGURE 5 | Denaturing gradient gel electrophoresis analysis of microbiota diversity. (A,B) DGGE profiles of rDNA amplicons obtained using universal primers (A) or Lactobacillus sp.-specific primers (B) on bacterial DNA isolated from fecal samples of sows (samples 1-12) or litters (13-24) belonging to untreated (13-16) or treated sow (17-24); (C,D) Graphical presentation of DGGE bands obtained using universal primers (C) or Lactobacillus sp.-specific primers (D). The numbers on the $x$-axis correspond to the numbers of lanes as presented in (A,B). Statistically relevant bands given in Table $\mathbf{2}$ are presented in boxes; (E,F) The average number of DGGE bands obtained using universal primers (E) or Lactobacillus sp.-specific primers (F) in specific groups (sows before probiotic treatment, litters of untreated sows and litters of treated sows). Statistically significant values compared to the control are marked with asterisks $\left({ }^{*} p<0.05\right)$.

bacteria by competitive colonization of probiotic strains before contact with pathogens from the environment.

A number of studies have been carried out in order to determine the efficiency of probiotics against intestinal infections in domestic animals (Kenny et al., 2011; Sornplang and Piyadeatsoontorn, 2016). Particularly, several microorganisms (bacteria and yeasts) were evaluated as potential probiotics for pigs (Tournut, 1989; Ezema, 2013). According to FAO/WHO (FAO-WHO, 2006), probiotics need to be non-pathogenic, non-toxic and have to exhibit beneficial effect on the host. Lactic acid bacteria are generally regarded as safe (GRAS). Moreover, in our previous studies the strains BGRA43 and BGHI14 were successfully used in animal experiments and determined as safe (Lukic et al., 2013; Strahinic et al., 2013), while the strain BGVLJ1-44 was isolated from artisanal yogurt and successfully used as starter culture for cheese manufacturing. In addition, all three strains are previously shown to be sensitive to the relevant antibiotics proposed by EFSA (European Food Safety Authority (EFSA), 2012; Golic et al., 2017).

In order to be effective in gut environment the probiotic should be capable to survive the GIT passage. Hence, the survival of the probiotic strains BGRA43, BGHI14 and BGVLJ1-44 in simulated GIT conditions was tested in this study. The obtained results suggested that all three strains could adequately survive the passage through stomach, while only two strains BGRA43 and BGVLJ1-44 survived the passage through dudenum (from initial $10^{8} \mathrm{CFU} / \mathrm{ml}$ to $10^{7} \mathrm{CFU} / \mathrm{ml}$ after incubation in gastric juice and bile salts; approximately $10 \%$ survival). Moreover, only the strains BGRA43 and BGVLJ1-44 successfully survived the conditions simulating colon environment $\left(10^{6} \mathrm{CFU} / \mathrm{ml}\right.$; survival approximately $1-2 \%)$. The number of viable cells of strain BGHI14 was quite lower $\left(10^{4} \mathrm{CFU} / \mathrm{ml}\right.$; survival approximately 
$0.01 \%$ ), hence this strain possibly exhibit beneficial effect as postbiotic. The best survival ability exhibited the EPS-producing strain BGVLJ1-44, which could survive even when applied in saline buffer. It could be hypothesized that the EPS layer present on the surface of BGVLJ1-44 helps the strain to deal with the harsh conditions in the gut environment, similarly to the previously reported Bifidobacterium animalis subsp. lactis strains (de los Reyes-Gavilán et al., 2011). However, the survival of other two strains BGRA43 and BGHI14 was achieved only when bacteria were applied in $1 \%$ skimmed milk. It was previously reported that food carriers, such as milk, favors survival through the GIT due to the buffering and protective effect (Ranadheera et al., 2010; Nikolic et al., 2012).

The colonization of intestinal mucosa, persistence in the gut and competitive exclusion of pathogens are the important probiotic features, according to FAO/WHO criteria (FAO-WHO, 2006). In fact, the health-promoting effects of probiotics partly depend on their ability to adhere to gut mucosa and to neutralize the effects of pathogens (Collado et al., 2009). This property is strain-dependent and could be achieved by different mechanisms, e.g., a physical blocking of the pathogen's binding to IEC (colonization competition), increasing the tight-junctions and reinforcing the permeability of the epithelium, induction of mucus production by IEC, as well as stimulation of the innate immune response (Gareau et al., 2010; Liévin-Le Moal and Servin, 2014). Moreover, the most promising property of probiotics used in piglets during the weaning period, is shown to be related to the ability to competitively exclude pathogenic (Angelakis, 2017). Thus, the ability of the strains and probiotic combination to competitively exclude E. coli ATCC25922 and Salmonella 654/7E was examined using Caco-2 cells. Here, we report that the strains used in this study, have moderate adhesion ability $(7-15 \%)$ enabling the strains to colonize the intestinal mucosa. The results revealed that the strain BGRA43 would be the most capable to compete with pathogens, particularly

TABLE 2 | Proportions of bands obtained in DGGE using U968-GC/L1401-r and Lab-0159f /Uni-0515-GCr primer pairs and corresponding $p$ values of Pearson chi-squared $(x 2)$ test.

\begin{tabular}{lccc}
\hline $\begin{array}{l}\text { Band number } \\
\text { (U968-GC/ } \\
\text { L1401-r) }\end{array}$ & $\begin{array}{c}\text { Proportion in piglets } \\
\text { from probiotic } \\
\text { treated mothers (\%) }\end{array}$ & $\begin{array}{c}\text { Proportion in piglets } \\
\text { from untreated } \\
\text { mothers (\%) }\end{array}$ & $\boldsymbol{p}\left(\boldsymbol{x}^{\mathbf{2}}\right)$ \\
\hline 77 & 75 & 0 & 0.014 \\
76 & 0 & 50 & 0.028 \\
75 & 75 & 0 & 0.014 \\
65 & 87.5 & 25 & 0.03 \\
63 & 87.5 & 25 & 0.03 \\
24 & 87.5 & 25 & 0.03 \\
20 & 0 & 50 & 0.028 \\
11 & 87.5 & 0 & 0.004 \\
10 & 12.5 & 100 & 0.004 \\
Band number & & & \\
(Lab-0159f / & & & \\
Uni-0515-GCr) & & 75 & 0.03 \\
45 & 12.5 & 50 & 0.028 \\
23 & 0 &
\end{tabular}

E. coli and Salmonella sp., to colonize the intestinal environment. In addition, the strain BGHI14, exhibiting the lowest adhesion ability, significantly $(p<0.05)$ reduced the adhesion of $E$. coli ATCC25922. Hence, it could be concluded that this feature is not correlated with the adhesion ability similarly as shown for the strain Lactobacillus paracasei BGSJ2-8 (Živković et al., 2016). Interestingly, the EPS-producing strain BGVLJ1-44 most significantly $(p<0.01)$ diminished the association of Salmonella $654 / 7 \mathrm{E}$ to Caco-2 cells, possibly due to the presence of ropy EPS at the cell surface. The results are in accordance to the previous findings suggesting that Salmonella 654/7E cells could not access the intestinal mucosa due to physical blocking of bacteria in EPS matrix (Živković et al., 2016). Moreover, the results of Polak-Berecka et al. (2014) indicated that EPS produced by L. rhamnosus $\mathrm{E} / \mathrm{N}$ hinder the adhesion of bacteria by masking the receptors at the host epithelial cell surface. However, the similar effect was not seen for E. coli ATCC25922 strain, pointing out that interactions between probiotics and pathogens are strain- (both probiotic and pathogen) dependent. The abilities of diverse probiotic strains to reduce the association of various pathogens to intestinal cells were previously reported, suggesting that this feature is most likely related to the presence of specific structural components on the bacterial cell surface including cell surface associated proteins, S-layer proteins, aggregation factors and EPS (Varma et al., 2010; Zhang et al., 2010; Kaewnopparat et al., 2013; García-Cayuela et al., 2014; Živković et al., 2015, 2016). Interestingly, the adhesion of Salmonella 654/7E in the presence of mixed probiotic culture was not reduced, indicating that possible antagonistic effects among the strains in probiotic mixture could be assumed.

Further, in this study we have treated the sows in the period of 10 days before the farrowing and the results revealed that the probiotic successfully reduced the number of viable cells of Enterobacteriaceae in litters of probiotic treated sows, confirming the results obtained in in vitro experiments showing ability of the probiotic strains to reduce association of E. coli and Salmonella to Caco-2 cells. Similarly, the literature data indicated that use of various lactobacillus probiotic strain L. paracasei, L. sobrius, L. rhamnosus GG decreased the count of Enterobacteriaceae, particularly E. coli and ETEC (Mozzi et al., 2015). In contrast, the treatment of grower and finisher pigs with various probiotic products based on Bacillus sp. showed inconsistent results, in one case Bacillus did not affect fecal LAB and E. coli counts, in other fecal LAB counts were increased while fecal coliform counts were not affected (Biomate 2B, Chr. Hansen Biosystems, Hoersholm, Danmark). When commercial product "Pelletmate livestock" (Chr. Hansen Biosystems) were supplemented, fecal coliform counts were decreased while LAB count was not affected, although increase in LAB, especially lactobacilli, was previously linked to health promoting effects in piglets and was inversely correlated with enterobacteria count (Pieper et al., 2009; Giang et al., 2011; Mozzi et al., 2015). Similarly to the results obtained for Bacillus sp. our results, obtained both by culture-dependent and DGGE method did not show significant differences in LAB counts between litters from treated and untreated sows. The discrepancy could be appointed to the fact that lactobacilli normally inhabit distal part of small intestine; 
hence the analysis of ileal microbiota would be needed to assess the influence of probiotic treatment of sows on total lactobacilli diversity in the litters (Tajima and Aminov, 2015).

Finally, the influence of probiotic on total microbiota diversity was evaluated and the significant increase of gut microbiota diversity in neonatal piglets was observed comparing to treated sows. The influence of probiotics on gut microbiota composition, diversity and function has been intensively studied recently, although the most data have been obtained in human studies (Hemarajata and Versalovic, 2013). For instance, DGGE analyses of human fecal microbiota of IBS patients revealed that microbiota composition was more similar in probiotics-treated patients than in the placebo group, suggesting that probiotics treatment stabilizes microbiota composition (Ki Cha et al., 2011). However, data related to influence of probiotics on piglets gut microbiota are limited. Recently, gnotobiotic piglets are used as a model to test the changes in gut microbiota composition in response to environmental factors. Similarly to the results of human studies, it was observed that the oral application of L. rhamnosus LGG in piglets prevented the changes in gut microbial composition caused by Human rhinovirus (HRV) infection (Zhang et al., 2014). The results of this study strongly indicate that gut microbiota diversity in piglets of treated sows is significantly increased comparing to their mother sows, while such increase was not scored in control groups.

\section{CONCLUSION}

According to our knowledge, this is the first study reporting that application of probiotic on sows positively influences the gut microbiota diversity in piglets. The results obtained in this study indicate that treatment of sows with new fermented dairy

\section{REFERENCES}

Angelakis, E. (2017). Weight gain by gut microbiota manipulation in productive animals. Microb. Pathog. 106, 162-170. doi: 10.1016/j.micpath.2016.11.002

Anonymous (1996). Microbiology of Food and Animal Feeding Stuffs - Horizontal Method for the Detection and Enumeration of Listeria monocytogenes - Part 1. Detection Method (ISO 11290-1:1996). Geneva: International Organization for Standardization.

Cappuccino, J. G., and Sherman, N. (2010). Microbiology: A Laboratory Manual, 9th Edn. San Francisco, CA: Pearson Education Inc., 185-188.

Castanon, J. I. R. (2007). History of the use of antibiotic as growth promoters in European poultry feeds. Poult. Sci. 86, 2466-2471. doi: 10.3382/ps.2007-00249

Cho, J. H., Zhao, P. Y., and Kim, I. H. (2011). Probiotics as a dietary additive for pigs: a review. J. Anim. Vet. Adv. 10, 2127-2134. doi: 10.2174/ 0929866524666170223143615

Collado, M. C., Isolauri, E., Salminen, S., and Sanz, Y. (2009). The impact of probiotic on gut health. Curr. Drug Metab. 10, 68-78. doi: 10.2174/ 138920009787048437

Collado, M. C., Meriluoto, J., and Salminen, S. (2007). Measurement of aggregation properties between probiotics and pathogens: in vitro evaluation of different methods. J. Microbiol. Methods 71, 71-74. doi: 10.1016/j.mimet.2007.07.005

de los Reyes-Gavilán, C. G., Suárez, A., Fernández-García, M., Margolles, A., Gueimonde, M., and Ruas-Madiedo, P. (2011). Adhesion of bile-adapted Bifidobacterium strains to the HT29-MTX cell line is modified after sequential gastrointestinal challenge simulated in vitro using human gastric and duodenal juices. Res. Microbiol. 162, 514-519. doi: 10.1016/j.resmic.2011.03.009 probiotic provides successful colonization of the piglets' gut with beneficial bacteria, improves the gut microbiota diversity and prevents the infection of neonatal piglets. Taking the results together it could be concluded that the probiotic would be a good candidate for application as feed additive in the pig industry for prevention of intestinal infections in neonatal piglets.

\section{AUTHOR CONTRIBUTIONS}

KV, AT-V, IM, and NG: conception and design of the study. $\mathrm{KV}$, AT-V, and NG: performed the main work. SM and JB: participated in the research - microbiology. MD, JL, and MŽ: participated in the research - host microbe interaction. KV and MT: participated in the research - DGGE analysis. JL: participated in the research - statistical analysis. IM: participated in the research - farm trial. NG, KV, AT-V, SM, and JL: analyzed, interpreted, and critically revised the data. KV and NG, prepared the manuscript for submission. All authors finally approved the version to be published.

\section{FUNDING}

The Ministry of Education, Science and Technological Development, Serbia (grant no. OI 173019 and Innovation Project, no. 451-03-2802/2013-16/148) supported this work.

\section{ACKNOWLEDGMENT}

Salmonella typhimurium Enteritidis 654/7E, veterinary isolate, was kindly provided by M. Velhner, Scientific Veterinary Institute "Novi Sad", Serbia.

European Food Safety Authority (EFSA) (2012). Guidance on the assessment of bacterial susceptibility to antimicrobials of human, and veterinary importance. EFSA panel on additives, and products or substances used in animal feed (FEEDAP). EFSA J. 10, 2740.

Ezema, C. (2013). Probiotics in animal production: a review. J. Vet. Med. Anim. Health 11, 308-316.

FAO-WHO (2006). Probiotics in Food: Health and Nutritional Properties and Guidelines for Evaluation. FAO Food and Nutritional Paper No. 85 (ISBN925-105513-105510). Rome: Food and Agriculture Organization of the United Nations-World Health Organization.

García-Cayuela, T., Korany, A. M., Bustos, I., Gómezde Cadiñanos, L. P., Requena, T., and Peláez, C. (2014). Adhesion abilities of dairy Lactobacillus plantarum strains showing an aggregation phenotype. Food Res. Int. 57, 44-50. doi: 10.1016/j.foodres.2014.01.010

Gareau, M. G., Sherman, P. M., and Walker, W. A. (2010). Probiotics and the gut microbiota in intestinal health and disease. Nat. Rev. Gastroenterol. Hepatol. 7, 503-514. doi: 10.1038/nrgastro.2010.117

Giang, H. H., Viet, T. Q., Ogle, B., and Lindberg, J. E. (2011). Effects of supplementation of probiotics on the performance, nutrient digestibility and faecal microflora in growing-finishing pigs. Asian Australas. J. Anim. Sci. 24, 655-661. doi: 10.5713/ajas.2011. 10238

Golic, N., Veljovic, K., Popovic, N., Djokic, J., Strahinic, I., Mrvaljevic, I., et al. (2017). In vitro and in vivo antagonistic activity of new probiotic culture against Clostridium difficile and Clostridium perfringens. BMC Microbiol. 17:108. doi: 10.1186/s12866-017-1015-5 
Hemarajata, P., and Versalovic, J. (2013). Effects of probiotics on gut microbiota: mechanisms of intestinal immunomodulation and neuromodulation. Therap. Adv. Gastroenterol. 6, 39-51. doi: 10.1177/1756283X12 459294

Kaewnopparat, S., Dangmanee, N., Kaewnopparat, N., Srichana, T., Chulasiri, M., and Settharaksa, S. (2013). In vitro probiotic properties of Lactobacillus fermentum SK5 isolated from vagina of a healthy woman. Anaerobe 22, 6-13. doi: 10.1016/j.anaerobe.2013.04.009

Kempler, G. M., and Mckay, L. L. (1981). Biochemistry and genetics of citrate utilization in Streptococcus lactis ssp. diacetylactis. J. Dairy Sci. 64, 1527-1539. doi: 10.3168/jds.S0022-0302(81)82721-X

Kenny, M., Smidt, H., Mengheri, E., and Miller, B. (2011). Probiotics - do they have a role in the pig industry? Animal 5, 462-470. doi: 10.1017/\$17517311100 0193X

Ki Cha, B., Mun Jung, S., Hwan Choi, C., Song, I., Woong Lee, H., Joon Kim, H., et al. (2011). The effect of a multispecies probiotic mixture on the symptoms and fecal microbiota in diarrhea-dominant irritable bowel syndrome: a randomized, double-blind, placebo-controlled trial. J. Clin. Gastroenterol. 46, 220-227. doi: 10.1097/MCG.0b013e31823712b1

Kojic, M., Fira, D., Banina, A., and Topisirovic, L. (1991). Characterization of the cell wall-bound proteinase of Lactobacillus casei HN14. Appl. Environ. Microbiol. 57, 1753-1757.

Konstantinov, S. R., Awati, A. A., Williams, B. A., Miller, B. G., Jones, P., Stokes, C. R., et al. (2006). Post-natal development of the porcine microbiota composition and activities. Environ. Microbiol. 8, 1191-1199. doi: 10.1111/j. 1462-2920.2006.01009.x

Kyriakis, S. C., Tsiloyiannis, V. K., Vlemmas, J., Sarris, K., Tsinas, A. C., Alexopoulos, C., et al. (1999). The effect of probiotic LSP 122 on the control of post-weaning diarrhoea syndrome of piglets. Res. Vet. Sci. 67, 223-228. doi: 10.1053/rvsc. 1999.0308

Li, B., and Chen, J. Q. (2013). Development of a sensitive and specific qPCR assay in conjunction with propidium monoazide for enhanced detection of live Salmonella spp. in food. BMC Microbiol. 13:273. doi: 10.1186/1471-218013-273

Liévin-Le Moal, V., and Servin, A. L. (2014). Anti-infective activities of Lactobacillus strains in the human intestinal microbiota: from probiotics to gastrointestinal anti-infectious biotherapeutic agents. Clin. Microbiol. Rev. 27, 167-199. doi: 10.1128/CMR.00080-13

Lukic, J., Strahinic, I., Milenkovic, M., Golic, N., Kojic, M., Topisirovic, L., et al. (2013). Interaction of Lactobacillus fermentum BGHI14 with rat colonic mucosa: implications for colitis induction. Appl. Environ. Microbiol. 79, 5735-5744. doi: 10.1128/AEM.01807-13

Mazmanian, S. K., Liu, C. H., Tzianabos, A. O., and Kasper, D. L. (2005). An immunomodulatory molecule of symbiotic bacteria directs maturation of the host immune system. Cell 122, 107-118. doi: 10.1016/j.cell.2005. 05.007

Mozzi, F., Raya, R. R., and Vignolo, G. M. (2015). Biotechnology of Lactic Acid Bacteria: Novel Applications. Ames, IA: Whiley Blackwell. doi: 10.1002/ 9781118868386

Nikolic, M., López, P., Strahinic, I., Suárez, A., Kojic, M., Fernández-García, M., et al. (2012). Characterisation of the exopolysaccharide 1 (EPS)-producing Lactobacillus paraplantarum BGCG11 and its non-EPS producing derivative strains as potential probiotics. Int. J. Food Microbiol. 158, 155-162. doi: 10.1016/ j.ijfoodmicro.2012.07.015

Pieper, R., Janczyk, P., Schumann, R., and Souffant, W. B. (2009). The intestinal microflora of piglets around weaning - with emphasis on lactobacilli. Arch Zootech. 9, 28-40.

Polak-Berecka, M., Waśko, A., Paduch, R., Skrzypek, T., and Sroka-Bartnicka, A. (2014). The effect of cell surface components on adhesion ability of Lactobacillus rhamnosus. Antonie Van Leeuwenhoek 106, 751-762. doi: 10.1007/ s10482-014-0245-x

Ranadheera, R. D. C. S., Baines, S. K., and Adams, M. C. (2010). Importance of food in probiotic efficacy. Food Res. Int. 43, 1-7. doi: 10.1016/j.foodres.2009. 09.009

Randazzo, C. L., Vaughan, E. E., and Caggia, C. (2006). Artisanal and experimental Pecorino Siciliano cheese: microbial dynamics during manufacture assessed by culturing and PCR-DGGE analyses. Int. J. Food Microbiol. 109, 1-8. doi: 10.1016/j.ijfoodmicro.2005.11.002
Sánchez, B., Fernández-García, M., Margolles, A., de los Reyes-Gavilán, C. G., and Ruas-Madiedo, P. (2010). Technological and probiotic selection criteria of a bile-adapted Bifidobacterium animalis subsp. lactis strain. Int. Dairy J. 20, 800-805. doi: 10.1016/j.idairyj.2010.06.004

Sornplang, P., and Piyadeatsoontorn, S. (2016). Probiotic isolates from unconventional sources: a review. J. Anim. Sci. Technol. 58, 26. doi: 10.1186/ s40781-016-0108-2

Strahinic, I., Lozo, J., Terzic-Vidojevic, A., Fira, D., Kojic, M., Golic, N., et al. (2013). Technological and probiotic potential of BGRA43 a natural isolate of Lactobacillus helveticus. Front. Microbiol. 4:2. doi: 10.3389/fmicb.2013. 00002

Tajima, K., and Aminov, R. (2015). "Structure and function of a nonruminant gut: a porcine model," in Rumen Microbiology: From Evolution to Revolution, eds A. K. Puniya, R. Singh, and D. N. Kamra (New Delhi: Springer).

Terzic-Vidojevic, A., Vukasinovic, M., Veljovic, K., Ostojic, M., and Topisirovic, L. (2007). Characterization of microflora in homemade semi-hard white Zlatar Cheese. Int. J. Food Microbiol. 114, 36-42. doi: 10.1016/j.ijfoodmicro.2006. 10.038

Timmerman, H. M., Koning, C. J. M., Mulder, L., Rombouts, F. M., and Beynen, A. C. (2004). Monostrain, multistrain and multispecies probiotics: a comparison of functionality and efficacy. Int. J. Food Microbiol. 96, 219-233. doi: 10.1016/j.ijfoodmicro.2004.05.012

Tournut, J. (1989). Applications of probiotics to animal husbandry. Rev. Sci. Tech. Off. Int. Epiz. 8, 551-556. doi: 10.20506/rst.8.2.413

Umesaki, Y., and Setoyama, H. (2000). Structure of the intestinal flora responsible for the development of the gut immune system in a rodent model. Microbes Infect. 2, 1343-1351. doi: 10.1016/S1286-4579(00)01288-0

van Winsen, R. L., Urlings, B. A. P., Lipman, L. J. A., Snijders, J. M. A., Keuzenkamp, D., Verheijden, J. H. M., et al. (2001). Effect of fermented feed on the microbial population of the gastrointestinal tracts of pigs. Appl. Environ. Microbiol. 67, 3071-3076. doi: 10.1128/AEM.67.7.30713076.2001

Varma, P., Dinesh, K. R., Menon, K. K., and Biswas, R. (2010). Lactobacillus fermentum isolated from human colonic mucosal biopsy inhibits the growth and adhesion of enteric and foodborne pathogens. J. Food Sci. 75, 546-551. doi: $10.1111 / j .1750-3841.2010 .01818 . x$

Wang, M., and Donovan, S. M. (2015). Human microbiota-associated swine: current progress and future opportunities. ILAR J. 56, 63-73. doi: 10.1093/ilar/ ilv006

Wang, Y., Gänzle, M. G., and Schwab, C. (2010). Exopolysaccharide synthesized by Lactobacillus reuteri decreases the ability of enterotoxigenic Escherichia coli to bind to porcine erythrocytes. Appl. Environ. Microbiol. 76, 4863-4866. doi: 10.1128/AEM.03137-09

Yang, Y., Galle, S., Le, M. H. A., Zijlstra, R. T., and Gänzle, M. G. (2015). Feed fermentation with reuteran- and levan-producing Lactobacillus reuteri reduces colonization of weanling pigs by enterotoxigenic Escherichia coli. Appl. Environ. Microbiol. 81, 5743-5752. doi: 10.1128/AEM.01525-15

Youmans, B. P., Ajami, N. J., Jiang, Z. D., Petrosino, J. F., DuPont, H. L., and Highlander, S. K. (2014). Development and accuracy of quantitative realtime polymerase chain reaction assays for detection and quantification of enterotoxigenic Escherichia coli (ETEC) heat labile and heat stable toxin genes in travelers' diarrhea samples. Am. J. Trop. Med. Hyg. 90, 124-132. doi: 10.4269/ ajtmh.13-0383

Zhang, H., Wang, H., Shepherd, M., Wen, K., Li, G., Yang, X., et al. (2014). Probiotics and virulent human rotavirus modulate the transplanted human gut microbiota in gnotobiotic pigs. Gut Pathog. 6:39. doi: 10.1186/s13099-0140039-8

Zhang, Y. C., Zhang, L. W., Tuo, Y. F., Guo, C. F., Yi, H. X., Li, J. Y., et al. (2010). Inhibition of Shigella sonnei adherence to HT-29 cells by lactobacilli from Chinese fermented food and preliminary characterization of S-layer protein involvement. Res. Microbiol. 161, 667-672. doi: 10.1016/j.resmic.2010. 06.005

Živković, M., Hidalgo-Cantabrana, C., Kojić, M., Gueimonde, M., Golić, N., and Ruas-Madiedo, P. (2015). Capability of exopolysaccharide-producing Lactobacillus paraplantarum BGCG11 and its non-producing isogenic strain $\mathrm{NB} 1$, to counteract the effect of enteropathogens upon the epithelial cell line HT29-MTX. Food Res. Int. 74, 199-207. doi: 10.1016/j.foodres.2015. 05.012 
Živković, M., Miljković, M., Ruas-Madiedo, P., Markelić, M., Veljović, K., Tolinački, M., et al. (2016). EPS-SJ exopolisaccharide produced by the strain Lactobacillus paracasei subsp. paracasei BGSJ2-8 is involved in adhesion to epithelial intestinal cells and decrease on E. coli association to Caco-2 cells. Front. Microbiol. 7:286. doi: 10.3389/fmicb.2016.00286

Zoetendal, E. G., Akkermans, A. D. L., Akkermans-Van Vliet, W. M., de Visser, J. A. G. M., and de Vos, W. M. (2001). The host genotype affects the bacterial community in the human gastrointestinal tract. Microb. Ecol. Health Dis. 13, 129-134. doi: 10.1080/089106001750462669

Zourari, A., Roger, S., Chabanet, C., and Desmazeaud, M. (1991). Caractérisation de bacteries lactiques thermophiles isolées de yaourts artisanaux grecs. Souches de Streptococcus salivarius subsp. thermophilus. Lait 71, 445-461. doi: 10.1051/ lait:1991434
Conflict of Interest Statement: The results presented in the manuscript are part of the national and PCT patent application submitted before the Intellectual Property Office, Serbia.

The reviewer RT and handling Editor declared their shared affiliation.

Copyright $\odot 2017$ Veljović, Dinić, Lukić, Mihajlović, Tolinački, Živković, Begović, Mrvaljević, Golić and Terzić-Vidojević. This is an open-access article distributed under the terms of the Creative Commons Attribution License (CC BY). The use, distribution or reproduction in other forums is permitted, provided the original author(s) or licensor are credited and that the original publication in this journal is cited, in accordance with accepted academic practice. No use, distribution or reproduction is permitted which does not comply with these terms. 